\title{
PENGEMBANGAN SISTEM INFORMASI BERBASIS WEB PADA USAHA “BALE FOOD” DALAM MENGHADAPI ERA DIGITAL 4.0
}

\author{
Isnawati \\ Fakultas Ekonomi dan Bisnis Universitas Mataram \\ isnawati.isna@unram.ac.id \\ Lukman Effendy \\ Fakultas Ekonomi dan Bisnis Universitas Mataram \\ lukman.effendy@unram.ac.id \\ Zuhrotul Isnaini \\ Fakultas Ekonomi dan Bisnis Universitas Mataram \\ zuhrotul.isnaini@unram.ac.id \\ Yusli Mariadi \\ Fakultas Ekonomi dan Bisnis Universitas Mataram \\ Yusli.mariadi@gmail.com
}

\section{Ringkasan}

"Bale Food" adalah salah satu usaha rumah tangga yang mencoba peruntungan di bidang kuliner berupa Kentang Kriuk ala nasi puyung. Usaha ini belum lama berjalan, namun sudah mendapatkan respon yang cukup baik dari konsumen, namun pengenalan produk oleh pemilik usaha "Bale Food" menggunakan fasilitas system informasi yang ada sekarang ini (seperti Facebook, Instagram) belum maksimal digunakan, terlebih lagi penggunaan web, sehingga informasi mengenai produk ini tentu belum sampai ke konsumen yang lebih luas.. Maka kegiatan pengabdian ini menjadi urgent dilakukan sebagai solusi untuk permasalahan tersebut. Adapun jenis kegiatan pengabdian ini adalah membantu usaha "Bale Food" untuk memasarkan produknya ke pasar yang lebih terbuka dan lebih luas melalui "Web". Oleh karena itu tim pengabdian nantinya akan membuatkan usaha "Bale Food" web. Metode Pelaksanaa pelaksanaan kegiatan pengabdian ini dilakukan dengan metode pembuatan web untuk usaha "Bale Food", dan nantinya pemilik usaha akan dilatih untuk menggunakan web itu. Kegiatan pengabdian sudah dilaksanakan sesuai dengan tujuan yang sudah dirumuskan yaitu membuatkan web untuk usaha "Bale Food". Adapun alamat / link web yang sudah berhasil dibuatkan untuk usaha "Bale Food" adalah https://balefood.blogspot.com.

\section{Kata Kunci : Sistem Informasi ; Era Digital 4.0; Web.}


Jurnal ABDIMAS INDEPENDEN

Vol. 1, No. 1, Mei 2020

\section{PENDAHULUAN}

\section{Latar Belakang}

Saat ini kita berada pada zama yang oleh banyak pakar disebut dengan zama revolusi Industri 4.0. Istilah Industri 4.0 ini menyatakan ide tentang revolusi industry keempat (Davies:2015 dalam Prasetyo dan Sutopo; 2018). Industri 4.0 merupakan fenomena yang unik yang diprediksi memiliki potensi manfaat yang besar. Sebagian besar pendapat mengenai potensi manfaat Industri 4.0 adalah mengenai perbaikan kecepatan fleksibilitas produksi, peningkatan pelayanan kepada pelanggan dan peningkatan pendapatan. Terwujudnya potensi manfaat tersebut akan memberikan dampak positif terhadap perekonomian suatu negara. Namun demikian, selain menwarkan potensi manfaat yang besar, namun juga sekaligus juga menawarkan tantangan yang harus dihadapi.

Drath dan Horch (2014) dalam Prasetyo dan Sutopo (2018) berpendapat bahwa tantangan yang dihadapi oleh suatu negara ketika menerapkan Industri 4.0 adalah munculnya resistensi terhadap perubahan demografi dan aspek social, ketidakstabilan kondisi politik, keterbatasan sumber daya, risiko bencana alam dan tuntutan penerapan teknologi yang ramah lingkungan. Kemajuan teknologi memungkinkan terjadinya otomatisasi hampir di semua bidang. Teknologi dan pendekatan baru yang menggabungkan dunia fisik, digital, dan biologi secara fundamental akan mengubah pola hidup dan interaksi manusia (Tjandrawinata; 2016). Selain itu juga Wolter dalam Yahya (2018) berhasil mengidentifikasi tantangan industry 4.0 sebagai berikut: 1) masalah keamanan teknologi informasi; 2) keandalan dan stabilitas mesin produksi; 3) kurangnya keterampilan yang memadai; 4) keengganan untuk berubah oleh para pemangku kepentingan; dan 5) hilangnya banyak pekerjaan karena berubah menjadi otomatisasi.

Pemetaan tantangan dan peluang industry 4.0 untuk mencegah berbagai dampak dalam kehidupan masyarakat, salah satunya adalah permasalahan pengangguran. Work Employment and Social Outlook Trend (2017) memprediksi 
jumlah orang menganggur secara global pada tahun 2018 diperkirakan akan mencapai 204 juta jiwa dengann kenaikan tambahan 2,7 juta. Hampir sama dengan kondisi yang dialami negara barat, Indonesia juga diprediksi mengalami hal yang sama. Pengangguran juga masih menjadi tantangan bahkan cendrung menjadi ancaman. Tingkat pengangguran terbuka Indonesia pada Februari 2017 sebesar $5,33 \%$ atau 7,01 juta jiwa dari total 131,55 juta orang angkatan kerja (BPS ; 2017).

Disaat Pemerintah mengupayakan berbagai upaya untuk mengurangi angka kemiskinan, tentunya kenyataan seperti ini akan menjadi ancaman bagi Pemerintah khususnya. Untuk itu Pemerintah harus membuka akan kondisi era digital saat ini, begitu juga bagi masyarakat yang menggerakkan perekenomian bangsa seperti para pengusaha, baik skala besar maupun skala kecil. Mau tidak mau harus ikut menyesuaikan diri dengan perubahan zaman seperti saat ini yang semuanya serba digital.

"Bale Food" adalah salah satu usaha rumah tangga yang mencoba peruntungan di bidang kuliner berupa Kentang Kriuk ala nasi puyung. Usaha ini belum lama berjalan, namun sudah mendapatkan respon yang cukup baik dari konsumen, terlihat dari jumlah permintaan yang terus meningkat setiap harinya. Saat ini, omset per harinya mencapai Rp. 500.000 per hari, bahkan bisa mencapai Rp.1.000.000 per harinya, dengan kata lain jika kita kalikan dengan 30 hari, maka omset produk ini bisa mencapai Rp.15.000 - Rp.30.000.000 per bulannya. Karena belum lama berdiri, maka produk ini baru dikenal hanya oleh konsumen local yang berada di sekitaran lokasi usaha, padahal produk ini memiliki potensi untuk digemari oleh konsumen luar. Terbukti beberapa konsumen yang sudah mengetahui produk ini, akan menjadikannya sebagai oleh-oleh jika hendak bepergian ke luar daerah. Bahkan beberapa dari mereka dari luar yang sudah mengetahui produk ini melakukan pemesanan via telepon yang ada di label produk. 


\section{Jurnal ABDIMAS INDEPENDEN}

Vol. 1, No. 1, Mei 2020

Pengenalan produk oleh pemilik usaha "Bale Food" menggunakan fasilitas system informasi yang ada sekarang ini (seperti Facebook, Instagram) belum maksimal digunakan, terlebih lagi penggunaan web, sehingga informasi mengenai produk ini tentu belum sampai ke konsumen yang lebih luas. Dengan era semua serba digital saat ini, tentu jika kita ingin usaha yang kita bangun bisa berkembang pesat, maka kita harus bisa memanfaatkan semua system informasi yang ada saat ini sebagai upaya kita untuk menyesuaikan diri dengan era digital saat ini.

\section{Permasalahan}

Uraian latar belakang menjelaskan bagaimana setiap usaha harus menyesuaikan diri dengan zaman yang serba canggih saat ini yang sering dikenal dengan era digital 4.0. dan "Bale Food" adalah salah satu jenis usaha rumahan yang punya potensi besar untuk berkembang karena keunggulan produknya, belum menyesuaikan diri dengan perkembangan zaman seperti ini. Hal ini terlihat dengan belum dimanfaatkannya system informasi yang ada saat ini untuk memasarkan produknya supaya bisa menjangkau pasar yang lebih luas.

\section{Tujuan Dan Manfaat}

Tujuan

Tujuan dilakukannya kegiatan pengabdian pada masyarakat ini adalah untuk memperluas jangkauan pemasaran untuk Usaha "Bale Food " dengan cara memanfaatkan media web, sehingga kegiatan ini bertujuan untuk membuatkan pemilik usaha web untuk usahanya.

\section{Manfaat}

Kegiatan pengabdian pada Masyarakat ini diharapkan dapat memperluas pemasaran dari usaha "Bale Food" dengan adanya pemanfaatan sarana pemasaran melalui Web, yang nantinya berimbas pada peningkatan penjualan dan mampu menjadikan usaha tersebut berkembang lebih besar tentunya. 


\section{SOLUSI DAN TARGET LUARAN}

\section{Solusi}

Berdasarkan uraian latar belakang dan rumusan masalah di atas, maka kegiatan pengabdian ini menjadi urgent dilakukan sebagai solusi untuk permasalahan tersebut. Adapun jenis kegiatan pengabdian ini adalah membantu usaha "Bale Food" untuk memasarkan produknya ke pasar yang lebih terbuka dan lebih luas melalui "Web". Oleh karena itu tim pengabdian nantinya akan membuatkan web untuk usaha "Bale Food.

\section{Target}

Target luaran yang diharapkan dari kegiatan ini adalah publikasi hasil kegiatan pengabdian berupa artikel pada salah satu media masa di Nusa Tenggara Barat (NTB) atau publikasi pada salah satu jurnal Pengabdian Kepada Masyarakat yang ada di Indonesia.

\section{Metode Pelaksanaan}

Pendekatan/metode pelaksanaan kegiatan pengabdian ini dilakukan dengan metode pembuatan web untuk usaha "Bale Food", dan nantinya pemilik usaha akan dilatih untuk menggunakan web itu. Sehingga pemilik usaha bisa memanfaatkan system informasi berbasis web tersebut untuk memasarkan produknya.

\section{HASIL DAN PEMBAHASAN}

\section{Gambaran Umum Ilmu Pengetahuan dan Teknologi (Iptek)}

\section{Sistem Informasi}

Informasi ibarat darah yang mengalir di dalam tubuh suatu organisasi. Sehingga informasi merupakan salah satu bentuk sumber daya utama dalam suatu organisasi yang yang digunakan oleh manajer untuk mengendalikan perusahaan dalam mencapai tujuan.

System informasi adalah sekumpulan hardware, software, brainware, prosedur dan atau aturan yang diorganisasikan secara integral untuk mengolah 


\section{Jurnal ABDIMAS INDEPENDEN}

Vol. 1, No. 1, Mei 2020

data menjadi iniformasi yang bermanfaat guna memecahkan masalah dan pengambilan keputusan. Definisi lain menyatakan bahwa system informasi adalah sekumpulan komponen pembentuk system yang mempunyai keterkaitan antara saru komponen dengan komponen lainnya yang bertujuan menghasilkan suatu informasi dalam suatu bidang tertentu. Dalam system informasi diperlukannya klasifikasi alur informasi, hal ini disebabkan keanekaragaman kebutuhan akan suatu informasi oleh pengguna informasi. Kriteria dari system informasi antara lain, fleksibel, efektif, dan efisien. Hasil dari proses system informasi akan digunakan pihak manajemen sebagai suatu dasar dalam pembuatan keputusan organisasi. Selain itu, system informasi yang baik juga dapat membantu dalam hal penganalisaan dan visualisasi masalah dalam penciptaan produk baru.

\section{Web}

\section{Definisi Web}

Secara umum Word Wide Web atau WWW atau juga dikenal dengan istilah WEB adalah salah satu layanan yang didapat oleh pemakai computer yang terhubung ke internet. Web ini menyediakan informasi bagi pemakai computer yang terhubung ke internet, dari sekedar informasi "sampah" atau informasi yang tidak berguna sama sekali sampai informasi yang serius; dari informasi yang gratisan sampai informasi yang komersial. Website atau situs dapat diartikan sebagai kumpulan halaman-halaman yang digunakan untuk menampilkan informasi teks, gambar diam atau gerak, animasi, suara, dan atau gabungan dari semuanya itu baik yang bersifat statis maupun dinamis yang membentuk satu rangkaian bangunan yang saling terkait, dimana masing-masing dihubungkan dengan jaringan-jaringan halaman (hyperlink).

Menurut Yuhefizar (--- ), Web merupakan suatu metode untuk menampilkan informasi di internet, baik berupa teks, gambar, suara maupun video yang interaktif dan mempunyai kelebihan untuk menghubungkan (link) 
satu dokumen dengan dokumen lainnya (hypertext) yang dapat diakses melalui sebuah browser.

\section{Cara Kerja Web}

Cara kerja Web dapat dijabarkan sebagai berikut:

a. Informasi Web disimpan dalam dokumen berupa halaman-halaman Web atau Web Page.

b. Halaman Web tersebut disimpan dalam komputer server Web

c. Sementara dipihak pemakai ada komputer yang bertindak sebagai komputer client dimana ditempatkan program untuk membaca halaman web yang ada di server web (browser)

d. Browser membaca halaman web yang ada di server web.

\section{Fungsi Web}

Secara umum situs web mempunyai fungsi sebagai berikut:

1. Fungsi komunikasi

Situs web yang mempunyai fungsi komunikasi pada umumnya adalah situs web dinamis. Karena dibuat menggunakan pemrograman web (ServerSide), maka dilengkapi fasilitas yang memberikan fungsi-fungsi komunikasi seperti, web mail, form contact, chatting form, dan yang lainnya.

2. Fungsi Informasi

Situs web yang memiliki fungsi informasi pada umumnya lebih menekankan pada kualitas bagian kontennya, karena tujuan situs tersebut adalah menyampaikan isinya. Situs ini sebaiknya berisi teks dan grafik yang dapat didownload cepat. Pembatasan penggunaan animasi gambar dan elemen bergerak seperti shockwafe dan java diyakini sebagai langkah yang tepat, diganti dengan fasilitas yang memberikan fungsi informasi seperti news, profile company, library reference, dIl.

\section{Fungsi Entertainment}




\section{Jurnal ABDIMAS INDEPENDEN}

Vol. 1, No. 1, Mei 2020

Situs web juga dapat memiliki fungsi entertainment/hiburan. Bila situs web kita berfungsi sebagai sarana hiburan, maka penggunaan animasi gambar dan elemen bergerak dapat meningkatkan mutu presentasi desainnya, meski tetap harus mempertimbangkan kecepatan downloadnya. Beberapa fasilitas yang memberikan fungsi hiburan adalah game online, film online, music online, dan sebagainya.

4. Fungsi Transaksi

Situs web dapat dijadikan sarana transaksi bisnis, baik barang, jasa atau lainnya. Situs web ini menghubungkan perusahaan, konsumen, dan komunikasi tertentu melalui transaksi elektronik. Pembayarannya bisa menggunakan kartu kredit, transfer, atau dengan membayar secara langsung.

\section{Sistem Informasi Berbasis Web}

Pengertian system informasi adalah mengelola dan mengolah data untuk menghasilkan informasi dan layanan kepada pengguna atau system informasi lain/ aplikasi lain. Sebuah system infromasi berbasis web biasanya terdiri dari satu atau lebih aplikasi web yang masing-masing komponen tersebut saling dukung satu dengan yang lainnya guna mencapai fungsi system informasi berbasis web secara umum. Untuk membentuk system informasi berbasis web tentunya harus memenuhi persyaratan setidaknya harus ada server yang mumpuni untuk mendukung system informasi tersebut. Saat ini Web Server yang paling terkenal adalah Apache Web Server. Selain itu juga harus ada Software pemrograman Web. Serta yang tak kalah pentingnya adalah database handal untuk menyimpan dan memanajemen data. Database yang dipergunakan harus mampu menangani berjuta-juta data dan dapat diakses dengan sangat cepat. 


\section{Gambaran Umum Usaha "Bale Food”}

Usaha "Bale Food" adalah salah satu bentuk usaha yang dimiliki oleh Ibu Ermawati dan keluarga yang beralamat di Jalan Banda Seraya BTN Seraya Mutiara Kavling 8 Pagutan. Usaha "Bale Food" ini menjual makanan ringan yang terbuat dari kentang. Jenis makanannya dinamakan "Kriuk Kentang" yang dibuat dengan 4 (empat) jenis / varian rasa yaitu : rasa original; rasa pedas; rasa paru; dan rasa teri.

Semua varian Kriuk Kentang Moikk berbahan dasar yang sama yaitu kentang yang dipotong kecil-kecil (bisa juga digobet / parut kasar), setelah itu digoreng sampai renyah. Kemudian didinginkan untuk nantinya dicampurkan sesuai dengan rasa yang sudah disediakan yaitu: teri, paru, cabe, bawang goreng. Berikut adalah gambar produk dari usaha "Bale Food":

Gambar 1: Produk Usaha "Bale Food" - Kriuk Kentang Moikkk
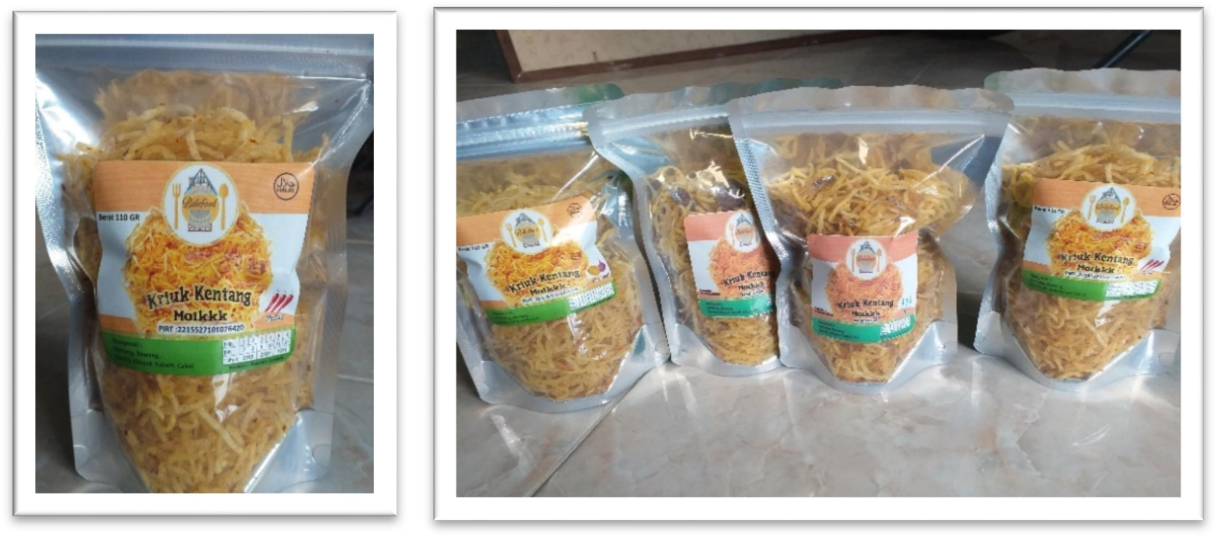

Sumber: Usaha "Bale Food". 2019

\section{HASIL DAN PEMBAHASAN}

Kegiatan pengabdian sudah dilaksanakan sesuai dengan tujuan yang sudah dirumuskan yaitu membuatkan web untuk usaha "Bale Food". Web ini nantinya akan dimanfaatkan untuk memperluas pasar dari produk yang dihasilkan oleh mitra, yaitu berupa kentang kriuk. 


\section{Jurnal ABDIMAS INDEPENDEN}

Vol. 1, No. 1, Mei 2020

Ada beberapa alasan yang membuat produk ini memerlukan web untuk memperluas jangkauan pasarnya. Salah satunya bahwa kentang kriuk ini bisa dikatakan sebagai salah produk khas Lombok, biasanya digunakan sebagai pelengkap dan menjadi salah satu ciri khas pada nasi "Puyung". Selain itu kentang kriuk ini berbahan dasar dari kentang, dimana diketahui bahwa kentang adalah salah satu bahan makanan yang sangat mudah diterima oleh semua kalangan dari anak-anak hingga orang dewasa. Dengan demikian produk ini memiliki peluang yang cukup potensial sehingga perlu untuk diperkenalkan ke masyarakat luas terutama masyarakat di luar Lombok. Mengingat juga produk ini sudah banyak menerim pesanan dari luar daerah seperti Jakarta, walaupun masih bersifat offline. Lebih lanjut lagi alasan produk ini memerlukan web sebagai salah satu wadah pemasarannya dikarenakan produk ini sudah memiliki syarat minimal untuk memiliki pasar online, terutama pada kemasan yang dinilai sudah cukup baik. Pembuatan web ini dilakukan oleh tim pengabdian melalui beberapa tahapan sebagai berikut:

a. Mengumpulkan data (informasi) yang dibutuhkan untuk pembuatan web, seperti identitas usaha berupa :nama usaha, pemilik usaha, jenis usaha, jenis produk, alamat usaha, nomor kontak pemilik usaha. Selain itu juga informasi yang dibutuhkan berupa dokumen foto produk yang akan dipasarkan melalui web.

b. Membuat akun email/gmail sebagai salah satu syarat pembuatan web yang dibutuhkan tersebut.

c. Membuatkan web untuk usaha "Bale Food". Adapun alamat / link web yang sudah berhasil dibuatkan untuk usaha "Bale Food" adalah https://balefood.blogspot.com. berikut adalah bagian tampilan dari web Usaha "Bale Food":

Gambar 2: Tampilan Web Usaha "Bale Food" 

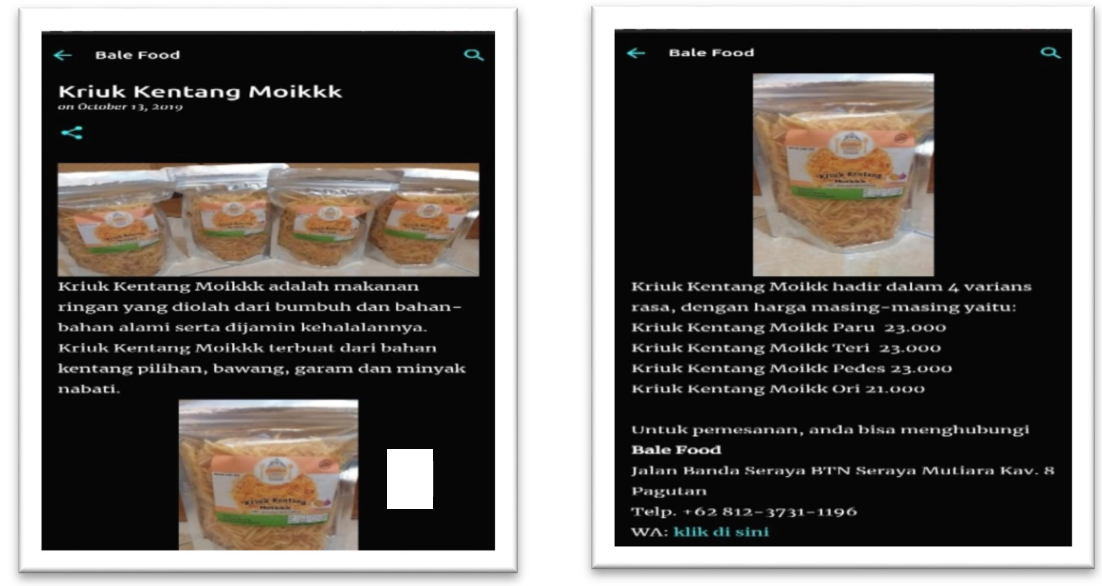

Sumber : https://balefood.blogspot.com

\title{
KESIMPULAN DAN SARAN
}

\begin{abstract}
KESIMPULAN
Kegiatan pengabdian sudah dilaksanakan sesuai dengan tujuan yang sudah dirumuskan yaitu membuatkan web untuk usaha "Bale Food". Web ini nantinya akan dimanfaatkan untuk memperluas pasar dari produk yang dihasilkan oleh mitra, yaitu berupa kentang kriuk. Adapun alamat / link web yang sudah berhasil dibuatkan untuk usaha "Bale Food" adalah https://balefood.blogspot.com. berikut adalah bagian tampilan dari web Usaha "Bale Food". Sehingga sekarang pemilik usaha akan mampu menjangkau pasar yang lebih luas lagi dengan adanya Web tersebut.
\end{abstract}

\section{SARAN}

Kegiatan pengabdian dengan metode pembuatan Web ini sangat penting terutama bagi usaha-usaha yang memiliki potensial untuk berkembang namun kurang mampu untuk menjangkau pasar yang lebih luas, terutama pasar-pasar di luar daerah. Namun sejauh ini kegiatan pengabdian ini belum mampu menjangkau usaha-usaha lainnya yang diyakini banyak jumlahnya. Oleh karena 
Jurnal ABDIMAS INDEPENDEN

Vol. 1, No. 1, Mei 2020

itu disarankan untuk menjangkau usaha yang lebih banyak lagi untuk kegiatan pengabdian berikutnya.

\section{DAFTAR PUSTAKA}

Badan Pusat Statistik Tahun 2017

Baswori dan Suwandi. 2008. Memahami Penelitian Kualitatif. Jakarta. Rineka Cipta.

Bogdan, Robert dan Steven taylor. 1992. Pengantar Metode Kualitatif. Surabaya. Usaha Nasional.

Davies, R. (2015). Industry 4.0 Digitalisation for productivity and growth. http://www.europarl.europa.eu/RegData/etudes/BRIE/2015/568337/EPRS _BRI(2015)568337_EN.pdf, Diunduh pada 11 Maret 2017.

Drath, R., \& Horch, A. (2014). Industrie 4.0: Hit or hype?[industry forum]. IEEE industrial electronics magazine, 8(2), pp. 56-58.

Heng, S. (2014). Industry 4.0: Upgrading of Germany's Industrial Capabilities on the Horizon. https://ssrn.com/abstract=2656608, Diakses pada 17 Juni 2017.

Kagermann, H., Lukas, W.D., \& Wahlster, W. (2013). Final report: Recommendations for implementing the strategic initiative INDUSTRIE 4.0. Industrie 4.0 Working Group.

Kamus Besar Bahasa Indonesia (KBBI) 
Qin, J., Liu, Y., \& Grosvenor, R. (2016). A Categorical Framework of Manufacturing for Industry 4.0 ana seyond. Procedia CIRP, Vol. 52, pp. 173178.

Sasongko, Nanang. 2002. Profesi Akuntan: Masa Kini dan Tantangan Masa Depan. Jurnal Ilmiah Akuntansi. Mei Vol.1 No.2. Fakultas Ekonomi. Universitas Jenderal Ahmad Yani.

Yahya, Muhammad. 2018. Era Industri 4.0: Tantangan dan peluang Perkembangan Pendidikan Kejuruan Indonesia. Pidato Sidang Terbuka Luar Biasa Senat Universitas Negeri Makasar tanggal 14 Maret 2018. 